УДК $630 * 892.6$

\title{
ГРУППОВОЙ СОСТАВ ЭКСТРАКТОВ ИЗ КРОНЫ ЛИСТВЕННИЦЫ СИБИРСКОЙ ЛЕТНЕГО И ОСЕННЕГО СБОРОВ
}

\author{
(C) Н.В. Транчук*, В.И. Рощцин
}

\author{
Санкт-Петербургский государственный лесотехнический университет \\ им. С.М. Кирова, Институтский пер., 5, Санкт-Петербург, 194021 (Россия), \\ e-mail: tran4uk@yandex.ru
}

Представлены результаты исследования содержания экстрактивных веществ древесной зелени лиственницы сибирской и отдельных ее частей (хвоя, кора, древесная часть побегов) летнего и осеннего сборов, а также опавшей хвои. Определено содержание экстрактивных веществ, извлекаемых органическими растворителями: петролейным и диэтиловым эфирами, этилацетатом, изопропиловым спиртом, а также эфирных масел. Определено, что хвоя лиственницы летнего сбора содержит меньше экстрактивных веществ, извлекаемых петролейным и диэтиловым эфирами, чем хвоя ели европейской, сосны обыкновенной и пихты сибирской, но сравнима по содержанию экстрактивных веществ, извлекаемых изопропиловым спиртом. Наиболее высокое содержание эфирных масел и экстрактивных веществ, извлекаемых петролейным и диэтиловым эфирами, этилацетатом, определено в коре побегов. В частях осеннего сырья (желтая хвоя с ветвей и побеги) содержание экстрактивных веществ, извлекаемых всеми растворителями, увеличивается, а содержание эфирных масел снижается.

Установлены групповые составы экстрактивных веществ всех частей каждого вида сырья, извлекаемых изопропиловым спиртом, а также групповые составы экстрактивных веществ, извлекаемых петролейным и диэтиловым эфирами из изопропанольного экстракта. Изопропанольный экстракт содержит в основном вещества, растворимые в петролейном эфире. Массовая доля веществ, извлекаемых последовательно диэтиловым эфиром и этилацетатом, после петролейного эфира значительно меньше.

Экстракт петролейного эфира, извлекаемый из изопропанольного экстракта коры побегов состоит на $60 \%$ из свободных кислот, древесной части побегов летнего сбора и побегов осеннего сбора - на $50 \%$ из свободных кислот, летней, и опавшей хвои - на 70\% из нейтральных веществ.

Экстракт диэтилового эфира, извлекаемый из изопропанольного экстракта различных частей каждого вида сырья, состоит в основном из веществ, извлекаемых бикарбонатом натрия (фенолокислоты). В экстракте диэтилового эфира летней и опавшей хвои содержится 28 и 40\% (здесь и далее от массы экстракта диэтилового эфира) веществ, извлекаемых водным раствором гидроксида натрия. Массовая доля нейтральных веществ в экстракте диэтилового эфира всех частей каждого вида сырья невелика (1-9\%), за исключением опавшей хвои $-25 \%$.

Ключевые слова: Larix sibirica (Ledeb.), экстрактивные вещества, фенольные соединения, липофильные соединения, древесная зелень, хвоя, побеги.

Работа выполнена при финансовой поддержке Министерства образования и науки Российской Федерачии (задание № 2014/181 «Создание научной базы переработки кроны лиственниць - отхода лесозаготовительной промышленности»).

\section{Введение}

Лиственница является главной лесообразующей породой России. Лиственничные леса занимают площадь в 278 млн га, что составляет 40\% от общей площади лесного фонда России [1].

В настоящее время описано восемь естественно произрастающих в России видов лиственницы: ли-

Транчук Наталия Владимировна - аспирантка, e-mail: tran4uk@yandex.ru

Рощин Виктор Иванович - заведующий кафедрой технологии лесохимических продуктов, химии древесины и физической химии, доктор химических наук, профессор, e-mail: kaf.chemdrev@mail.ru ственница Сукачева; сибирская, Гмелина, или даурская, Каяндера, охотская, ольгинская, курильская, камчатская. Лиственница сибирская Larix sibirica (Ledeb.) - один из наиболее распространенных и важнейших лесообразующих видов рода

\footnotetext{
* Автор, с которым следует вести переписку.
} 
Larix. С севера на юг ее ареал простирается от южного побережья Белого моря до юга Сибири и Монголии, с запада на восток - от Онежской губы до Забайкалья. Лиственница сибирская занимает $14 \%$ от всех лиственничных лесов нашей страны [1].

Общеизвестным фактом является то, что древесная зелень хвойных деревьев чрезвычайно богата биологически активными веществами. Существуют определенные сложности для промышленной переработки древесной зелени лиственницы, такие как сезонная смена сырья: в летний вегетационный период сырьем являются охвоенные побеги, в осенний - побеги без хвои.

В литературе имеются данные по изучению химического состава фенольных соединений хвои лиственницы сибирской [2-4], жирнокислотного состава липидов тканей почек [5], в работе [6] исследован состав триглицеридов камбиальной зоны ствола и древесной зелени лиственницы сибирской, проведены работы по изучению влияния белков и фосфолипидов в почках в процессе покоя и вегетации [7], подробно изучен состав живицы [8] и эфирных масел из различных частей древесной зелени [9-13].Огромный вклад в изучение и разработку комплексной безотходной технологии переработки биомассы лиственницы сибирской с получением широкого набора практически значимых и биологически активных продуктов внесен лабораторией химии древесины ИрИХ СО РАН $[14,15]$. Подобные программы разрабатывались и другими специалистами [16].

Цель данного исследования - изучение группового состава фракций липофильных и фенольных соединений из разных частей древесной зелени лиственницы сибирской.

\section{Экспериментальная часть}

Объектом исследования является древесная зелень лиственницы сибирской. Пробы сырья были отобраны 28 июля 2013 г. в Турунтаевском лесничестве Томской области (летний сбор) и 30 октября 2013 г. в ботаническом саду Санкт-Петербургского лесотехнического университета (СПбГЛТУ) (осенний сбор). Ботанический вид отобранных образцов древесной зелени подтвержден кафедрой ботаники и дендрологии СПбГЛТУ им. С.М. Кирова.

Под термином «древесная зелень» понимают охвоенные ветви (побеги) диаметром до 1 см. Летом среднюю пробу древесной зелени собирали со срубленного дерева по всей высоте ствола (высота дерева 17,6 м, диаметр на высоте 0,3 - 0,36 м, диаметр на высоте 1,3 - 0,28 м). Диаметр отобранных охвоенных побегов 3-7 мм. Осенним сырьем являлись побеги с желтой хвоей, опавшая хвоя, собранная с почвы, и обесхвоенные побеги с дерева. Диаметр отобранных осенних ветвей (побегов) с желтой хвоей 3-5 мм, располагались на высоте 1,5-3,0 м над уровнем земли. Сырье делили на несколько частей: летнее - хвоя, кора, древесина, соотношение которых по массе составило $4: 2: 1$; осеннее - желтая хвоя, побеги, хвоя, собранная с почвы.

Сырье характеризовали по содержанию влаги методом высушивания при $105{ }^{\circ} \mathrm{C}$, экстрактивных веществ (ЭВ) путем экстракции отдельных частей исходного сырья различными растворителями в аппаратах Сокслета емкостью 50 мл при температуре кипения растворителя. В качестве экстрагентов использовали: пропан-2-ол (изопропиловый спирт, ИП), петролейный эфир (пределы кипения $40-70{ }^{\circ} \mathrm{C}$; ПЭ), диэтиловый эфир (ДЭ), этилацетат (ЭА) [17]. Определение веществ, летучих с паром, проводили методом гидродистилляции [18].

Для изучения групповых составов и дальнейших исследований ЭВ нарабатывали из измельченного сырья путем экстракции изопропанолом в аппарате Сокслета емкостью 1,0 л в течение 8 ч. ИП удаляли под вакуумом. Концентрированный экстракт разбавляли водой в соотношении $1: 1$ и последовательно трехкратно экстрагировали растворителями различной полярности при соотношение экстракт - растворитель $1: 1$ :

- ПЭ (пределы кипения $40-70{ }^{\circ} \mathrm{C}$ ) - для извлечения липофильных соединений;

- ДЭ - для извлечения фенольных соединений (ФС);

- ЭА - для выделения полярных ФС и их гликозидов [19].

Последовательную экстракцию растворителями проводили при температуре ниже температуры кипения растворителя на $5-10{ }^{\circ} \mathrm{C}$. Схема наработки ЭВ изображена на рисунке.

Экстрактивные вещества, растворимые в ПЭ, разделили на группы веществ по кислотно-щелочной схеме [20].

Вещества, растворимые в ДЭ, делили на три условно названные группы:

- фенолокислоты - обработкой экстракта 1\% раствором гидрокарбоната натрия;

- фенолы - обработкой экстракта $2 \%$ раствором щелочи;

- нейтральные соединения - вещества, не извлекаемые щелочными реагентами. 


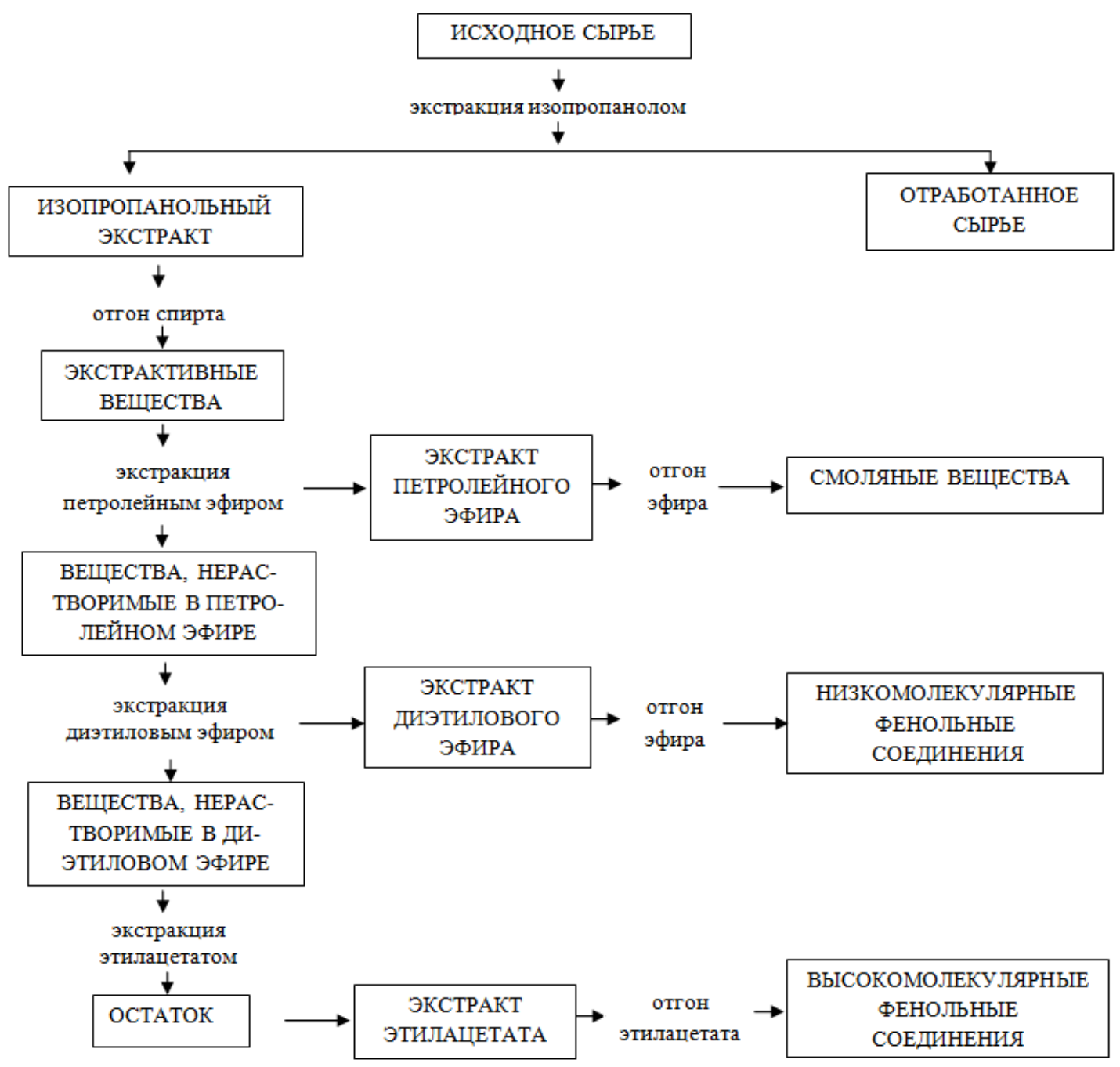

Схема наработки ЭВ из различных частей кроны лиственницы

Вещества, перешедшие в водно-бикарбонатный и водно-щелочной растворы, экстрагировали ДЭ после подкисления растворов $10 \%$ серной кислотой. В составе фракции фенолокислот после подкисления часть соединений имела ограниченную растворимость в ДЭ. Такие соединения извлекали путем дополнительной экстракции подкисленного водно-бикарбонатного раствора ЭА. Результаты ТСХ этих экстрактов показали, что состав веществ, извлекаемых ДЭ и ЭА из подкисленного водно-бикарбонатного раствора, близок (согласно значениям Rf и окраске пятен). Для дальнейшей работы эти экстракты объединили. ИКспектры отдельных фракций записаны на приборе ИК-фурье спектрометр ФСМ 1201 со спектральным диапазоном 400-5000 $\mathrm{cm}^{-1}$, в таблетках $\mathrm{KBr}$.

\section{Обсуждение результатов}

Влажность сырья летнего сбора составила: 44\% - для хвои, 22\% - для коры, 26\% - для древесной части побегов; для хвои и побегов осеннего сбора - 54 и 23\% соответственно. Образцы разных частей древесной зелени летнего и осеннего сборов характеризовали по содержанию ЭВ, растворимых в различных растворителях (табл. 1).

Из результатов анализа сырья, приведенных в таблице 1, видно, что выход экстрактивных веществ увеличивается с повышением полярности применяемого растворителя. Наибольшее содержание ЭВ, извлекаемых эфирами и ЭА из разных частей древесной зелени, определено в коре. В хвое отмечено наиболее высокое содержание ЭВ, экстрагируемых спиртом. В древесной части побегов содержится наименьшее количество ЭВ. Учитывая соотношение в побегах коры и древесной части 2 : 1, можно предположить, что побеги летнего сбора содержат меньше ЭВ, чем побеги осеннего сбора. 
Таблица 1. Содержание экстрактивных веществ в различных частях древесной зелени (процент от массы сухого сырья)

\begin{tabular}{c|c|c|c|c|c}
\hline \multirow{2}{*}{ Группы соединений } & \multicolumn{3}{|c|}{ Летнее сырье } & \multicolumn{2}{|c}{ Осеннее сырье } \\
\cline { 2 - 6 } & хвоя & $\begin{array}{c}\text { древесная } \\
\text { часть }\end{array}$ & кора & $\begin{array}{c}\text { хвоя } \\
\text { (желтая, с веток) }\end{array}$ & побеги \\
\hline Вещества, экстрагируемые & 2,5 & 3,9 & 10,6 & 4,6 & 10,2 \\
петролейным эфиром & 7,2 & 5,7 & 12,3 & 7,4 & 14,4 \\
диэтиловым эфиром & 12,6 & 8,0 & 15,0 & 14,7 & 16,2 \\
этилацетатом & 32,8 & 11,9 & 19,8 & 21,7 & 19,4 \\
изопропиловым спиртом & 0,52 & 0,38 & 1,96 & 0,1 & 0,2 \\
Вещества, летучие с паром & 0,96 & \\
\hline
\end{tabular}

В осенний период, по сравнению с летним, общее содержание ЭВ в хвое снижается (экстракция ИП), но увеличивается в побегах. Вероятно, в осенний период в хвое происходит накопление липофильных соединений и веществ, растворимых в ЭА, но снижается содержание более полярных ЭВ. Содержание соединений, растворимых в ДЭ, в хвое летнего и осеннего сборов примерно одинаково. В осенних побегах содержание ЭВ, извлекаемых растворителями разной природы, выше, чем в летних.

Содержание веществ, экстрагируемых ПЭ и ДЭ, в хвое лиственницы сибирской меньше, чем в хвое ели, пихты и сосны (для ели: 7,8 и 9,8\%, для пихты: 10,1 и 19,3\%, для сосны: 15,0 и 22,0\% соответственно). Хвоя лиственницы уступает и по содержанию веществ, растворимых в ИП (в летний период 32,8\%), хвое ели $(38,6 \%)$ и пихты $(37,3 \%)$, за исключением хвои сосны (30,9\%). Побеги лиственницы, особенно осеннего сбора, превосходят побеги сосны и ели по содержанию ЭВ, извлекаемых ДЭ и ПЭ, уступая по количеству последних лишь побегам пихты. ЭА извлекает из частей древесной зелени лиственницы больше веществ, чем из частей древесной зелени сосны, пихты и ели, уступая лишь по содержанию таких соединений в коре пихты [19-24].

Наибольшее количество веществ, летучих с водяным паром, в летнем сырье обнаружено в коре, наименьшее - в древесине. В хвое осеннего сбора эфирного масла в два раза меньше, чем в побегах, и значительно меньше, чем в частях древесной зелени летнего сбора.

ИП экстракт делили на группы веществ, растворимых в различных растворителях, с повышением их полярности. Результаты представлены в таблице 2.

При сравнении результатов, приведенных в таблицах 1 и 2, следует, что выходы ИП экстрактов при определении содержания ЭВ и для их наработки практически одинаковы, за исключением экстрактов, полученных из древесной части летних побегов и осенней хвои. Возможно, это связано с тем, что для наработки ЭВ использовалась уже опавшая хвоя, а для определения содержания ЭВ - желтая хвоя с дерева.

Данная схема исследования ИП экстракта позволяет при выделении растворимых в ПЭ веществ изучить состав и малополярных компонентов экстракта, которые являются основой продуктов, получаемых при промышленной переработке древесной зелени с использованием в качестве экстрагента углеводородных растворителей [20]. Количество ЭВ, извлекаемых ПЭ из ИП экстракта, ближе к их количеству, выделяемому в производственных условиях углеводородным экстрагентом из древесной зелени с использованием экстракторов оросительно-дефлегмационного типа [22].

Из ИП экстракта ПЭ извлекает больше веществ, чем непосредственно из сырья (табл. 1 и 2). Основная масса липофильных соединений содержится в ветвях обоих сборов, а из опавшей хвои их выход значительно ниже, чем из летней хвои (в процентах от массы сухого сырья). Смолистые вещества составляют основную часть ИП экстракта коры и осенней опавшей хвои, что почти в четыре раза больше, чем в молодой хвое.

Таблица 2. Выход ИП экстракта

\begin{tabular}{|c|c|c|c|c|}
\hline \multirow{2}{*}{ Исходное сырье } & \multicolumn{4}{|c|}{ Содержание экстрактивных веществ (процент от массы сухого сырья), извлекаемых } \\
\hline & пропанол-2 & петролейный эфир & диэтиловый эфир & этилацетат \\
\hline \multicolumn{5}{|c|}{ Летний сбор } \\
\hline Древесная зелень & $\ldots$ & $41,7 / 13,3$ & $\ldots$ & $\ldots$ \\
\hline Хвоя & 33,2 & $21,0 / 6,9 *$ & $3,2 / 1,1$ & $4,7 / 1,6$ \\
\hline Древесная часть & 6,3 & $36,1 / 4,3$ & $2,7 / 0,2$ & $9,4 / 0,6$ \\
\hline Kopa & 21,0 & $88,9 / 17,6$ & $4,8 / 1,0$ & $2,1 / 0,4$ \\
\hline \multicolumn{5}{|c|}{ Осенний сбор } \\
\hline Хвоя (опавшая) & 6,8 & $76,9 / 5,2$ & $10,5 / 0,7$ & $4,2 / 0,3$ \\
\hline Побеги & 25,0 & $40,0 / 10,0$ & $11,5 / 2,9$ & $5,7 / 1,4$ \\
\hline
\end{tabular}

* В числителе - содержание веществ в процентах от ИП экстракта, в знаменателе - от массы сухого сырья. 
По данным ИК-спектроскопии ЭВ, извлекаемые из ИП экстракта ДЭ и ЭА, содержат фенольные соединения: слабая полоса в области 1510-1514 $\mathrm{cm}^{-1}$ и сильная полоса в области 1610-1616 см${ }^{-1}$ [25].

В сырье летнего сбора преобладают соединения, растворимые в ЭА. При этом максимальный выход таких веществ наблюдается в хвое и древесной части побегов. Выход соединений, растворимых в ДЭ, в хвое и коре побегов летнего сырья примерно одинаков. Следует отметить, что хвоя летнего сбора лидирует по суммарному содержанию фенольных соединений, в то время как в древесной части побегов содержится их минимальное количество (в прцентах от массы сухого сырья).

В осеннем сырье содержание соединений, растворимых в ДЭ, почти вдвое превышает содержание веществ, растворимых в ЭА. Суммарное содержание фенольных соединений в осенних побегах в несколько раз выше, чем в опавшей хвое.

Общее содержание фенольных соединений в осеннем сырье выше, чем в летнем.

Выделенные из ИП экстракта вещества, растворимые в ПЭ и ДЭ, разделены на группы соединений (табл. 3 и 4).

Групповой состав ЭВ из разных частей древесной зелени значительно различается. Экстракты древесной части и хвои обоих сборов в основном состоят из нейтральных веществ и близки по содержанию неомыляемых соединений. В экстрактах из древесной зелени и коры побегов содержание свободных кислот и нейтральных веществ примерно одинаково, но содержание в последних связанных кислот и неомыляемых веществ различно. Свободные кислоты в наименьшем количестве содержатся в хвое осеннего сбора.

Хвоя лиственницы сибирской более богата по содержанию нейтральных веществ, чем хвоя сосны (44,5\%) и пихты (51,9\%), а по количеству свободных кислот не уступает хвое ели (21,9\%). В побегах лиственницы обнаружено больше свободных кислот, чем в побегах пихты $(44,4 \%)$, сосны $(53,0 \%)$ и ели $(40,8 \%)$, а количество нейтральных веществ близко к их содержанию в побегах сосны $(45,2 \%)$ [20-22].

Из результатов исследования, представленных в таблице 4, следует, что фенолокислоты являются доминирующей группой фенольных соединений. Наибольшее их количество сосредоточено в побегах летнего и осеннего сборов. Группа фенолов составляет меньшую часть веществ, основная их масса содержится в хвое. Нейтральные вещества содержатся в незначительных количествах, за исключением хвои осеннего сбора.

Побеги лиственницы по сравнению с побегами ели отличаются высоким содержанием фенолокислот (для ели: 46-50\% от массы экстракта). В осенней хвое лиственницы содержится больше фенолов и нейтральных веществ, чем в еловой хвое (30-36 и 10-12\% от массы экстракта соответственно) [20, 24].

Согласно приведенным данным можно проследить изменения в накоплении и расходовании ЭВ: к осени в хвое и побегах лиственницы количество фенолов и нейтральных веществ значительно увеличивается, причем основная их масса накапливается в хвое. При этом количество фенолокислот в частях древесной зелени к осени уменьшается (в хвое - вдвое).

Таблица 3. Групповой состав петролейноэфирной части ИП экстракта (процент от массы ПЭ экстракта)

\begin{tabular}{|c|c|c|c|c|c|c|}
\hline \multirow[b]{2}{*}{ Группы соединений } & \multicolumn{4}{|c|}{ Летнее сырье } & \multicolumn{2}{|c|}{ Осеннее сырье } \\
\hline & $\begin{array}{c}\text { древесная } \\
\text { зелень }\end{array}$ & Хвоя & $\begin{array}{c}\text { древесная } \\
\text { часть }\end{array}$ & кора & Хвоя & побеги \\
\hline Свободные кислоты & 60,3 & 31,5 & 48,0 & 60,5 & 21,7 & 51,8 \\
\hline $\begin{array}{l}\text { Нейтральные вещества, } \\
\text { в том числе: }\end{array}$ & 39,0 & 67,5 & 51,3 & 39,2 & 67,8 & 44,7 \\
\hline неомыляемые вещества & 27,6 & 43,1 & 19,8 & 19,4 & 40,1 & 27,3 \\
\hline связанные кислоты & 10,3 & 16,4 & 28,1 & 16,1 & 21,8 & 12,62 \\
\hline
\end{tabular}

Таблица 4. Групповой состав веществ, растворимых в диэтиловом эфире ИП экстракта (процент от массы ДЭ экстракта)

\begin{tabular}{l|c|c|c}
\hline \multirow{2}{*}{$\begin{array}{c}\text { Исходное } \\
\text { сырье }\end{array}$} & \multicolumn{3}{c}{ Группы фенольных соединений } \\
\cline { 2 - 4 } & фенолокислоты & фенолы & нейтральные вещества \\
\hline \multicolumn{5}{|c}{ Летний сбор } \\
\hline Хвоя & 44,3 & 28,8 & 4,4 \\
Древесная часть & 82,1 & 6,3 & 1,1 \\
Кора & 75,8 & 6,1 & 2,1 \\
\hline \multicolumn{7}{|c|}{ Осенний сбор } \\
\hline Хвоя (опавшая) & 23,3 & 40,5 & 25,0 \\
Побеги & 64,6 & 16,9 & 9,3 \\
\hline
\end{tabular}




\section{Выводы}

1. Определено, что основной группой веществ изопропанольного экстракта разных частей кроны лиственницы являются липофильные соединения. Экстракт петролейного эфира летней древесной зелени, коры побегов и осенних побегов на 50-60\% состоит из свободных кислот; нейтральные вещества являются основной группой липофильных соединений хвои обоих сборов.

2. Летом в хвое лиственницы содержание фенольных соединений (веществ, экстрагируемых ДЭ и ЭА из ИП экстракта) выше, чем в осенний период. В побегах, напротив, к осени содержание фенольных соединений увеличивается, среди них доминирующими являются менее полярные вещества. Это, возможно, связано с тем, что в период листопада необходимые для жизнедеятельности дерева вещества перемещаются из хвои в ветви.

3. Доминирующей группой липофильных соединений является группа нейтральных веществ, их наибольшее содержание определено в молодой и опавшей хвое, основной группой фенольных соединений являются фенолокислоты, их основное количество определено в летних и осенних побегах.

4. Ряд показателей групповых составов экстрактов кроны лиственницы сибирской, особенно осеннего сбора, превышает подобные показатели в древесной зелени других хвойных пород, что предполагает возможность ее использования для химической переработки с получением биологически активных продуктов.

\section{Список литературы}

1. Милютин Л.И. Биоразнообразие лиственниц России // Хвойные бореальной зоны. 2003. №1. С. 6-9.

2. Медведева С.А. Исследование фенольных соединений хвои некоторых видов пихты и лиственницы : дис. ... канд. хим. наук. Новосибирск, 1973. 138 с.

3. Тюкавкина Н.А., Медведева С.А., Иванова С.З., Луцкий В.И. Лигнановые соединения хвои некоторых видов семейства Ріnaceae // Химия древесины. 1977. №6. С. 94-96.

4. Варкасина Т.Н., Иванова Т.Г. Флавоноидные гликозиды в хвое лиственницы сибирской (Larix sibirica) // Изучение природы лесов Сибири : материалы третьей конференции молодых ученых. Красноярск, 1972. С. 107-111.

5. Алаудинова Е.В., Миронов П.В., Репях С.М. Жирные кислоты мембранных липидов живых тканей почек лиственницы сибирской // Химия растительного сырья. 2000. №2. С. 41-45.

6. Рубчевская Л.П. Липиды хвойных растений семейства Pinaceae : автореф. дис. ... д-ра хим. наук. Красноярск, 1997. $33 \mathrm{c}$

7. Миронов П.В. Физико-химические процессы в тканях хвойных при низких температурах : дис. ... д-ра хим. наук. Красноярск, 2001. 367 с.

8. Пентегова В.А., Дубовенко Ж.В., Ралдугин В.О., Шмидт Э.Н. Терпеноиды хвойных растений. Новосибирск, 1987. $96 \mathrm{c}$.

9. Левин Э.Д., Репях С.М. Переработка древесной зелени. М., 1984. 120 с.

10. Holm Y., Hiltunen R. Variation and inheritance of monoterpenes in Larix species // Flavour and fragrance journal. 1997. Vol. 12, issue 5. Pp. 335-339.

11. Чекушина Н.В., Шаталина Н.В., Ефремов А.А. Состав эфирного масла лиственницы сибирской // Химия растительного сырья. 2008. №3. С. 103-105.

12. Панькив О.Г., Паршикова В.Н., Слащенин Д.Г., Степень Р.А. Динамика липидов и их некоторых компонентов древесной зелени лиственницы сибирской // Химия растительного сырья. 2009. №3. С. 99-102.

13. Трошина A.B., Рощин B.И. Состав эфирных масел из отдельных частей кроны лиственницы сибирской (Larix sibirica LDB) // Новые достижения в химии и химической технологии растительного сырья : матер. 5 Bcepoc. конф. с междунар. участием. Барнаул, 2012. Т. 1. С. 225-228.

14. Бабкин В.А., Остроухова Л.А., Дьячкова С.Г., Святкин Ю.К., Бабкин Д.В., Онучина Н.А. Безотходная комплексная переработка биомассы лиственницы сибирской и даурской // Химия в интересах устойчивого развития. 1997. Т. 5. С. 105-115.

15. Бабкин В.А., Остроухова Л.А., Иванова С.З., Иванова Н.В., Медведева Е.Н., Малков Ю.А., Трофимова Н.Н., Федорова Т.Е. Продукты глубокой химической переработки биомассы лиственницы. Технология получения и перспективы использования // Российский химический журнал. 2004. T. XLVIII, №3. С. 62-69.

16. Кузнецова С.А., Данилов В.Г., Кузнецов Б.Н., Яценкова О.В., Жижаев А.М. Новый интегрированные процесс комплексной переработки древесины лиственницы в ценные химические продукты // Хвойные бореальной зоны. 2003. №1. С. 96-100.

17. Оболенская А.В., Ельницкая 3.П., Леонович А.А. Лабораторные работы по химии древесины и целлюлозы. M., $1991.320 \mathrm{c}$.

18. Ушанова В.М., Лебедева О.И., Девятловская А.Н. Основы научных исследований. Ч. 2. Контроль качества и экстрагирование растительного сырья. Красноярск, 2003. 168 с.

19. Артемкина Н.А. Низкомолекулярные фенольные соединения древесной зелени ели европейской Picea Abies (L) Karst : дис. ... канд. хим. наук. СПб., 2001. 177 с.

20. Рощин В.И., Баранова Р.А., Белозерских О.А., Соловьев В.А. Состав экстрактивных веществ хвои и побегов ели европейской // Химия древесины. 1983. №4. С. 56-61.

21. Колодынская Л.А., Разина Н.Ю., Рощин В.И., Соловьев В.А. О различии в групповом составе экстрактивных веществ хвои и побегов сосны обыкновенной // Химия древесины. 1984. №5. С. 74-78. 
22. Рощин В.И., Колодынская Л.А., Баранова Р.А., Нагибина Н.Ю. Состав экстрактивных веществ древесной зелени пихты сибирской // Химия древесины. 1989. №5. С. 96-105.

23. Репях С.М., Чупрова Н.А., Барабаш Н.Д. Экстрактивные вещества древесной зелени // Химия древесины. 1983. №4. C. 62-65.

24. Фелеке А.С. Фенольные соединения древесной зелени ели европейской Picea Abies (L) Karst : дис. ... канд. хим. наук. СПб., 1997. 135 с.

25. Наканиси К. Инфракрасные спектры и строение органических соединений. М., 1965. 216 с.

Поступило в редакиию 15 апреля 2015 г.

После переработки 28 октября 2015 г.

Tranchuk N.V. ${ }^{*}$, Roshchin V.I. THE LIPOPHILIC AND PHENOLIC GROUP COMPOSITION IN DIFFERENT PARTS OF THE SIBERIAN LARCH WOOD GREEN

St. Petersburg State Forest Technical University named in honour of S.M. Kirov, 5, Institutskiy pereulok,

St.Petersburg, 194021 (Russia), e-mail:tran4uk@yandex.ru

The results of extractive compounds contain research in the different parts of the Siberian larch crown (needles, bark, wood part of twigs) collected in summer and autumn and fallen-down needles are presented. The extractive compounds and essential oils contains extracted by organic solvents (petroleum and diethyl ethers, ethyl acetate and isopropyl alcohol) are detected. It is defined that the Siberian larch needles contain less extractive compounds (extracted by petroleum and diethyl ethers) than fir spruce needles, Scotch pine needles and Siberian fir needles, but they may be compared by isopropanol soluble extractives. The main quantity of the essential oils and extractives soluble in petroleum and diethyl ethers, ethyl acetate is detected in twig bark. Autumn collected needles and twigs extractives contain (extracted by all solvent kinds) increase, contain of essential oils is decrease.

The group composition of the isopropyl alcohol extractives of all kinds of raw materials and the group composition of petroleum and diethyl ethers extracts are presented. The main part of the isopropanol extract is petroleum ether soluble fraction (lipophilic fraction).

The twig bark lipophilic fraction (of the isopropanol extract) consists of free acids for $60 \%$, twig wood part collected in summer and autumn twigs lipophilic fractions consist of free acids for $50 \%$, the lipophilic fractions of summer needles and fallen-down needles consist of neutral compounds for $70 \%$.

The main part of diethyl ether extract (obtained from isopropanol extract) of the all kinds of raw materials consists of phenolic acids (substances which may be extracted by aqueous sodium hydrogencarbonate). Summer needles and fallen-down needles diethyl ether extracts consist of substances which may be extracted by aqueous caustic for $28 \%$ and $40 \%$.

The main content of the diethyl ether neutral compounds is detected in fallen-down needles. It is $25 \%$.

Keywords: Larix Sibirica (Ledeb.), extractive compounds, phenolic compounds, lipophilic compounds, wood green, needles, twigs.

\footnotetext{
* Corresponding author.
} 


\section{References}

1. Miliutin L.I. Khvoinye boreal'noi zony, 2003, no. 1, pp. 6-9. (in Russ.).

2. Medvedeva S.A. Issledovanie fenol'nykh soedinenii khvoi nekotorykh vidov pikhty i listvennitsy: dis. ... kand. khim. nauk. [Study of phenolic compounds needles of some species of fir and larch: the dissertation Candidate of Chemical Science]. Novosibirsk, 1973, 138 p. (in Russ.).

3. Tiukavkina N.A., Medvedeva S.A., Ivanova S.Z., Lutskii V.I. Khimiia drevesiny, 1977, no. 6, pp. 94-96. (in Russ.).

4. Varkasina T.N., Ivanova T.G. Izuchenie prirody lesov Sibiri : materialy tret'ei konferentsii molodykh uchenykh. [The study of the nature of the forests of Siberia: Proceedings of the Third Conference of Young Scientists]. Krasnoyarsk, 1972, pp. 107-111. (in Russ.).

5. Alaudinova E.V., Mironov P.V., Repiakh S.M. Khimiia rastitel'nogo syr'ia, 2000, no. 2, pp. 41-45. (in Russ.).

6. Rubchevskaia L.P. Lipidy khvoinykh rastenii semeistva Pinaceae : avtoref. dis. ... d-ra khim. nauk. [Lipids coniferous plant family Pinaceae: Abstract of the thesis of the doctor of chemical sciences]. Krasnoyarsk, 1997, 33 p. (in Russ.).

7. Mironov P.V. Fiziko-khimicheskie protsessy v tkaniakh khvoinykh pri nizkikh temperaturakh : dis. ... d-ra khim. nauk. [Physical and chemical processes in the tissues of conifers at low temperatures: the Dissertation of the doctor of chemical sciences]. Krasnoyarsk, 2001, 367 p. (in Russ.).

8. Pentegova V.A., Dubovenko Zh.V., Raldugin V.O., Shmidt E.N. Terpenoidy khvoinykh rastenii. [Terpenoids conifers]. Novosibirsk, 1987, 96 p. (in Russ.).

9. Levin E.D., Repiakh S.M. Pererabotka drevesnoi zeleni. [Recycling wood greens]. Moscow, 1984, 120 p. (in Russ.)

10. Holm Y., Hiltunen R. Flavour and fragrance journal, 1997, vol. 12, issue 5, pp. 335-339.

11. Chekushina N.V., Shatalina N.V., Efremov A.A. Khimiia rastitel'nogo syr'ia, 2008, no. 3, pp. 103-105. (in Russ.).

12. Pan'kiv O.G., Parshikova V.N., Slashchenin D.G., Stepen' R.A. Khimiia rastitel'nogo syr'ia, 2009, no. 3, pp. 99-102. (in Russ.).

13. Troshina A.V., Roshchin V.I. Novye dostizheniia v khimii i khimicheskoi tekhnologii rastitel'nogo syr'ia : mater. 5 Vseros. konf. s mezhdunar. uchastiem. [Advances in chemistry and chemical technology of vegetable raw materials: materials 5 All-Russian conference with international participation]. Barnaul, 2012, vol. 1, pp. 225-228. (in Russ.).

14. Babkin V.A., Ostroukhova L.A., D'iachkova S.G., Sviatkin Iu.K., Babkin D.V., Onuchina N.A. Khimiia v interesakh ustoichivogo razvitiia, 1997, vol. 5, pp. 105-115. (in Russ.).

15. Babkin V.A., Ostroukhova L.A., Ivanova S.Z., Ivanova N.V., Medvedeva E.N., Malkov Iu.A., Trofimova N.N., Fedorova T.E. Rossiiskii khimicheskii zhurnal, 2004, vol. XLVIII, no. 3, pp. 62-69. (in Russ.).

16. Kuznetsova S.A., Danilov V.G., Kuznetsov B.N., Iatsenkova O.V., Zhizhaev A.M. Khvoinye boreal'noi zony, 2003, no. 1, pp. 96-100. (in Russ.).

17. Obolenskaia A.V., El'nitskaia Z.P., Leonovich A.A. Laboratornye raboty po khimii drevesiny i tselliulozy. [Laboratory work on the chemistry of wood and cellulose]. Moscow, 1991, 320 p. (in Russ.).

18. Ushanova V.M., Lebedeva O.I., Deviatlovskaia A.N. Osnovy nauchnykh issledovanii. Ch. 2. Kontrol' kachestva i ekstragirovanie rastitel'nogo syr'ia. [Basic scientific research. Part 2. Quality control and extraction of vegetable raw materi]. Krasnoyarsk, 2003, 168 p. (in Russ.).

19. Artemkina N.A. Nizkomolekuliarnye fenol'nye soedineniia drevesnoi zeleni eli evropeiskoi Picea Abies (L) Karst : dis. ... kand. khim. nauk. [Low molecular weight phenolic compounds woody green spruce Picea Abies (L) Karst: the thesis Candidate of Chemical Science]. St. Petersburg, 2001, 177 p. (in Russ.).

20. Roshchin V.I., Baranova R.A., Belozerskikh O.A., Solov'ev V.A. Khimiia drevesiny, 1983, no. 4, pp. 56-61. (in Russ.).

21. Kolodynskaia L.A., Razina N.Iu., Roshchin V.I., Solov'ev V.A. Khimiia drevesiny, 1984, no. 5, pp. 74-78. (in Russ.).

22. Roshchin V.I., Kolodynskaia L.A., Baranova R.A., Nagibina N.Iu. Khimiia drevesiny, 1989, no. 5, pp. 96-105. (in Russ.).

23. Repiakh S.M., Chuprova N.A., Barabash N.D. Khimiia drevesiny, 1983, no. 4, pp. 62-65. (in Russ.).

24. Feleke A.S. Fenol'nye soedineniia drevesnoi zeleni eli evropeiskoi Picea Abies (L) Karst : dis. ... kand. khim. nauk. [Phenolic compounds of wood greens of spruce Picea Abies (L) Karst: the thesis Candidate of Chemical Science]. St. Petersburg, 1997. 135 c. (in Russ.).

25. Nakanisi K. Infrakrasnye spektry $i$ stroenie organicheskikh soedinenii. [Infrared spectra and structure of organic compounds]. Moscow, 1965, 216 p. (in Russ.). 